TITLE:

\title{
Motivations for organic farming in tourist regions: a case study in Nepal
}

$\operatorname{AUTHOR}(S):$

Aoki, Misa

\section{CITATION:}

Aoki, Misa. Motivations for organic farming in to urist regions: a case study in Nepal. Environment, Development and Sustainability 2013, 16(1): 181-193

ISSUE DATE:

2013-06-05

URL:

http://hdl.handle.net/2433/197129

\section{RIGHT:}

The final publication is available at Springer via http://dx.doi.org/10.1007/s10668-0139469-6; この論文は出版社版でありません。引用の際には出版社版をご確認ご利用くだ さい。; This is not the published version. Please cite only the published version. 


\title{
Motivations for organic farming in tourist regions: a case study in Nepal
}

\begin{abstract}
An increasing number of individuals and businesses involved in the tourism industry have begun activities related to organic farming and organic agro-products not only in Europe and North America but also in developing countries in Asia. Both organic farming and rural tourism are considered important to socially and economically sustainable rural development. The influences on the establishment of or conversion to organic farming have been much discussed in Europe but not in developing countries. This study focuses on Nepal, where small-scale organic farming occurs in tourism areas, and qualitatively reveals the motivations for organic farming and other factors related to its adoption. It was found that the reasons for introducing organic farming practices varied with the timing of their adoption. Additionally, the kinds of organic-related activities adopted varied depending on how the individual adopter first encountered the term 'organic farming'. However, all individuals involved in organic farming shared some common motivations, such as desires for personal health, quality produce and rural development.
\end{abstract}

Keywords Organic farming, Diffusion, Tourist region, Rural development, Nepal 


\section{Introduction}

An increasing number of individuals and businesses involved in the tourism industry have begun activities related to organic farming and organic agroproducts not only in Europe and North America but also in developing countries in Asia. Both organic farming and rural tourism are considered to have a wide and varied range of functions (OECD 2001), which are important in socially and economically sustainable rural development.

Various definitions of organic farming exist. Lampkin (1994) defined organic farming as farming that "creates integrated, humane, environmentally and economically sustainable production systems.” The International Federation of Organic Agriculture (IFOAM) presented the following definition: "Organic agriculture is a production system that sustains the health of soils, ecosystems and people. It relies on ecological processes, biodiversity and cycles adapted to local conditions, rather than the use of inputs with adverse effects." Though these definitions differ, it is commonly agreed that organic farming is an environmentally friendly production system and a method of sustainable agriculture (Scofield 1986; Sharma 2001; Hansen et al. 2001; Bowler 1992; Pretty 1995; Stolze 2000). Besides its positive effect on the environment, organic farming has functions such as job creation, income generation, development of new technologies mixed with indigenous knowledge (Scialabba 2000) and network construction (Hamilton and Fischer 2003; Wu and Pretty 2004). This multi-functionality of organic farming is thought to offer advantages in rural development (Darnhofer 2005).

Parrott et al. (2006) identified two types of organic farming in developing countries: officially certified organic farming and informal organic farming. The first tends to focus on the export of organic products, while the second involves small-scale activities to improve the livelihoods of individual farmers (Goldberger 2008). Because certification systems are necessary to access international markets, it is important to develop domestic markets for crops produced through informal organic farming (Parrott et al. 2006). Rural tourism can contribute significantly to the development of such markets (Pinheiro et al. 2002).

Rural tourism is defined as "a discrete activity with distinct characteristics which may vary in intensity and by area” (Lane 1994). The development of rural tourism offers potential solutions to various issues that rural areas face, such as 
income growth (Fuller 1990), building diversified and sustainable economies (UNDP 1992; Gannon 1994; Greffe 1992) and halting the decline of traditional agrarian industries (Cavaco 1995; Opperman 1996). In particular, farm-based tourism in rural areas, called agri-tourism, has been defined as "a set of activities that occur when people link travel with products, services and experiences of agriculture” (Maetzold 2002). Concerns regarding environmental problems have increased interest in sustainable tourism, such as eco-tourism. Sustainable tourism involves activities that respect and preserve the natural, cultural and social integrity of the region. Under these conditions, including organic farming in agritourism is important to future rural development (Kuo and Chiu 2006; Hyungsuk 2009; Privitera 2010).

The influences on the establishment of or conversion to organic farming have been discussed in detail. Several authors have noted that such influences can vary depending on farm scale and the stage of diffusion at which farmers adopt organic practices (Rogers 1995; Padel 2001), while Weymes (1999) showed that profitability is a crucial factor. A study of small-scale farmers in developing countries also indicated that farmers have various motivations for engaging in organic farming, as well as receiving varied training and information from local nongovernmental organizations (NGOs). (Akiyama 2012; Kafle 2011).

Few studies have focused on motivations for and other factors related to the introduction of organic farming in the context of agri-tourism in developing countries. This study investigated such motivations and factors in a chronological context for organic farming in the hilly tourist regions of Nepal. Nepal presents an ideal study opportunity because most farmers engage in small-scale family level organic farming in a tourism context. The study was qualitative and used the classification established by Padel (2001). The study data provide a reference for consideration of the future development of tourism-related organic farming.

\section{Organic Farming in Nepal}

Nepal reportedly has 1,470 organic farmers who cultivate a total area of 9,898 ha (Willer and Kilcher 2012, 2013). Both the number of organic farmers and the area cultivated have increased during the last decade (Table 1). However, these figures may greatly underestimate the actual scale of organic farming in Nepal, 
since its hilly and mountainous areas have been little affected by the Green Revolution, and many farmers still rely on traditional farming methods that are based on mixed crop-animal farming without chemical inputs (Devendra and Thomas 2001; Pokhrel and Pant 2009). In fact, the 2010-11 Nepal Living Standards Survey (CBS 2011) reported that about 71\% of farmers do not use improved seeds, and $63 \%$ of vegetable famers are not reliant on chemical fertilizers. Thus, more than half of the farmers in the hilly and mountainous areas of Nepal can be assumed to produce crops and vegetables using traditional and/or organic methods.

The special circumstances of Nepal mean that some residents do not differentiate between traditional farming practices and organic farming (Aoki 2011). Organic farming thus is not a new concept in the Nepalese context, where a high percentage of agriculture is largely organic by default to maintain soil fertility and production. Therefore, little effort is required to convert existing systems to become so-called organic, for example by introducing improved composting practices and improved pest management using bio-fertilizers and bio-pesticides (Pokhrel and Pant 2009; Mandal and Resources 2007). Some farms in southern Nepal produce vegetables using methods that combine indigenous and conventional knowledge (Pant, 2006). Organic farming in Nepal thus uses traditional and indigenous knowledge to introduce selected modern technologies to manage and enhance farming diversity, and to ecologically intensify production. Bhatta et al. (2009) pointed out that conversion to organic farming definitely helps empower farmers and local communities through using local resources and self-reliance.

Though the importance of organic farming in Nepal is realized by both farmers and policy makers, such as the government and NGOs, the market for organic products remains poorly developed. The national government first declared its support for organic farming in 2004, and emphasized organic certification and enhanced local participation in food quality management to provide market incentives (MOAC 2004). Also, the National Standards of Organic Agriculture Production and Processing 2007 have been implemented and the organic certification body constructed. However, this official certification system is not yet operational. Additionally, even if the certification system were 
operational, certification costs would constrain increased certification of organic products for small-scale farmers (Bhat 2009).

One way to overcome the constraint that the niche market for organic products places on organic farming is to practice organic farming in the context of tourism. Tourism is one of the biggest industries in Nepal, and some tourism regions, such as Pokhara, have introduced organic farming activities to the industry. For instance, some hotels that own their own farmland practice organic farming and serve guests meals cooked with organic produce. However, few studies have examined the relationship between organic farming and tourism in developing countries.

\section{Survey and Methodology}

\subsection{Survey outline and study area}

This study was conducted in Pokhara, which is located in the Kaski district, a hilly area located at medium altitude in central Nepal. This study investigates the motivations driving individuals to initiate and continue organic farming activities in the study area. Since published market statistics on organic products in the study area were unavailable, a field survey was conducted over a 1-month period: from September 3, 2009 to October 3, 2009. The contact details of hotels, restaurants and shops in Pokhara city and the surrounding rural areas were supplied by the Nepal Tourism Board, Pokhara Hotel Association and Pokhara Restaurant Association. The resulting list contained the phone numbers or email addresses of over 120 establishments. Each establishment was questioned on whether they owned an organic farm or used organic agro-products. Thirteen establishments provided positive responses, including 10 hotels and three organic shops. A detailed interview survey and farm visits were conducted to determine the motivations and other factors related to the organic farming activities of the positive respondents.

The study area, Pokhara, is a famous city in Nepal, noted for its beautiful landscape and wildlife. The city is the economic, political and cultural centre of the Kaski district and has a population of 219,215 living in 52,317 households (ISRC 2008). The main economic activities are agriculture and tourism. Around 
half of the working population is engaged in agriculture and approximately 75,000 tourists visit the region annually (PTC 2008). According to Adhikari and Seddon (2002), chemical fertilizers and pesticides were first introduced to farmers in this area in the early 1970s. Around 14\% of farmers in Pokhara began using modern methods at this time. As urbanization and economic development increased, farmers who were richer or living in urban areas expanded their use of modern farming methods (Adhikari 2005). The local government did not implement policy support for organic farming, and NGOs, farmers groups and foreign aid organizations thus engaged in such activities of their own accord. The promotion of organic farming in rural areas of Pokhara by local NGOs began in 1992, while international NGOs and foreign aid organizations established organic farming projects around 1995. Such initiatives have gradually spread organic farming practices. However, residents of Pokhara, especially those with a long involvement in tourism, became acquainted with the term 'organic' before the above organizations began their activities, having been introduced to the phrase by foreign tourists concerned about personal health, the environment or wildlife (Aoki 2011).

\subsection{Analysis method}

Both economic and non-economic factors are related to organic farming establishment of conversion (Fisher 1989). Based on this knowledge, Padel (2001) categorized the motivations of farmers who convert to organic farming by summarizing previous European studies. Kafle (2011) previously concluded that the diffusion of organic farming in Nepal depended on farm size and the way farmers collected information about organic farming. Therefore, this study sought to clarify these motivations and factors qualitatively based on the categorization of Padel (2001), while also considering the timing of individuals beginning to engage in organic activities. Additionally, an attempt was made to categorize the motivations of individuals obtaining information on organic farming, when they became aware of the term 'organic' and whether they were members of local NGOs. Consideration was also given to the two definitions of 'organic' prevalent in Nepal: first, that organic farming is a new approach that tries to increase efficiency by growing a variety of crops and vegetables without chemical inputs 
(Ramesh et al. 2005), and second, that organic farming includes all farming that does not rely on chemical inputs, whether using new approaches or traditional ones. Thus, this survey tried to establish the role of these two concepts in the uptake or conversion to organic-related activities. Table 2 shows the categorization of factors and motivations related to conversion to organic farming in this study.

\section{Results and Discussion}

Based on the data collected in this field survey, the motivations for and other factors related to undertaking organic farming were categorized as shown in Table 3. Although this categorization was based on Table 2, several categories from Table 2 have been omitted. Omitted categories included animal health problems, financial problems, securing the farm's future, ergonomic reasons and stewardship. Moreover, omission was based on no respondents citing such motivations. Instead, a new motivation category that cited the desire of guests to visit hotels or restaurants was included, because some individuals reported that this had prompted them to introduce organic-related activities. With the exception of restaurant/hotel $\mathrm{B}$, most respondents in the hotel/restaurants subgroup ran hotels with attached restaurants. Respondent B was unique in the subgroup for being solely a restaurant. Table 3 lists respondents in chronological order according to when they began their organic activities.

\subsection{Respondent attributes and organic farmland}

The earliest individual to begin organic farming started in 1979, more than 10 years before NGOs or foreign aid agencies started promoting such activities in the area. This indicates some early local interest in organic farming. In the latter half of the 1990s, more hotels or restaurants became active in organic farming, which indicates that the subgroup hotels/restaurants tended to become active before the organic shops, which became active in organic farming only after 2006. Most respondents had been farmers in their previous jobs, living in the rural areas around Pokhara. Such individuals came to the city to start businesses in response 
to the increasing numbers of tourists, and through their contact with tourists were likely aware of health and environmental issues.

Some of the hotels/restaurants owned large areas of farmland in the city and in nearby rural areas. Others used small areas of farmland in their backyards. Both groups used produce from their farmland in their meals. Previous studies have noted that farmers who own larger farms start organic farming earlier (Rogers 1995 and Kafle 2011). However, this trend was not observed in the present study. The organic shops did not own their own farmland, but instead sold the products of farmers groups or NGOs engaged in organic farming. The individuals in the hotels/restaurants subgroup tended not to participate in the organic farming projects of local NGOs, while the shop managers did participate in such projects.

\subsection{Information sources and the concept of 'organic' food}

The sources of information that influenced the adoption of organic farming seemed to be correlated with the time at which the business began its activities. The earliest people to become acquainted with the term 'organic' tended to have obtained their information from foreign tourists, for example when hotel guests asked if their meals were cooked with organic vegetables. According to Table 3, manager $\mathrm{C}$ claimed he started organic farming before he even became aware of the term 'organic'. This implies that after becoming aware of organic farming from foreign tourists, he came to regard organic farming as traditional farming, which does not use chemical fertilizers or pesticides. After 1990, some people began to learn from foreign organic agriculture trainers, mostly affiliated with international NGOs. This training inspired these individuals to implement the organic concept in tourism. During this period, individuals started organic farming to add value to other services they already provided, having obtained information on organic farming from the internet, or from acquaintances who were already practitioners. In 2000, some individuals opened organic shops in response to information from local NGOs and hearing about organic farming from neighbors who were members of farmers groups. The events described above explain the variety of information sources responsible for current awareness of the term 'organic'. 
The respondents' interpretation of the term 'organic' also seemed related to the time at which they became aware of it. The earliest respondents to become familiar with the term tended to think of organic farming as traditional farming, which had long been practiced in the area. This group were concerned about environmental destruction, health risks and the decline of rural areas caused by rapid urbanization and economic development. In the latter half of the 1990s, another group of individuals emerged who considered organic farming a new style of farming intended to improve technological and economic efficiency without using chemical inputs or improved seeds. Although the Nepalese government has established definitions for the terms traditional farming and organic farming ${ }^{1}$, this survey indicates that these official definitions are not used in practice, or that foreign tourists or NGOs strongly influence the interpretation of the term 'organic'. Table 4 summarizes the two concepts of organic farming discussed in this section.

\subsection{Motivations for the introduction of organic farming}

\subsubsection{Farming-related and personal motives}

The main motivation for the introduction of organic farming in tourist areas is probably increased profits based on the added value of offering organic products and meals for wealthier consumers (Table 3). This survey defines premium marketing as pricing meals containing organic produce higher than those made from conventional produce, or the advertisement of organic-related activities to target wealthier consumers. Respondents adopting this approach primarily emerged after 1990 and tended to target guests from developed countries. Some such individuals increased the price of their meals by $35 \%$ relative to non-organic

\footnotetext{
1 The Government of Nepal defines traditional, modern and organic agriculture as follows: Traditional agriculture: a farming system that has been developed by utilizing the long-held knowledge and wisdom in the region. Modern agriculture: a farming system that uses chemical inputs, such as chemical fertilizers, pesticides, hormones and improved seeds. Organic agriculture: a farming system that merges various technologies in order to maintain a sustainable environment. This concept is based on the definition by IFOAM (International Federation of Organic Agriculture Movement), which states that organic agriculture should include the principles of health, ecology, fairness and stewardship.
} 
equivalents. In contrast, the hotel/restaurants that began their organic-related activities before 2000 did not target added value in their marketing. In fact, these individuals did not actively advertise their organic-related activities to seek profit but simply practiced organic farming out of health and environmental concerns.

These different motivations also depend on what the respondents understand the meaning of 'organic farming' to be. Those who considered 'organic farming' a technologically and economically efficient method of farming tended to be influenced by the associated market premium, while those who did not differentiate between 'organic farming' and traditional farming likely simply wished to better maintain their farmland.

The personal motivations of most individuals were to solve their personal and family health problems. They worried that agrochemicals could damage their health based on the stories of farmer neighbors who suffered from diarrhea and vomiting when using chemical pesticides. Such information regarding the negative health effects of chemicals has spread throughout the area. The other motivation of many individuals was a desire to maintain produce quality. This is because these individuals had previous experience of farming and believed they could distinguish foods grown with chemicals from those grown without. Some such individuals claimed that although chemicals increase crop yield and vegetable size, the resultant produce tasted worse than chemical-free produce. Few individuals were motivated to practice traditional or organic farming to conserve local natural resources. Health is therefore a more important motivating factor than concern for the environment.

The desires of guests were an important factor that motivated several individuals to become involved in organic activities. These individuals first encountered the concept of organic farming through guests who frequently asked if they used organic produce to prepare their meals. For this group of respondents, almost half of their guests were Westerners and more than 20\% were repeat visitors. For these respondents, their involvement in organic activities was likely to attract guests with particular interests in health or environmental issues. 


\subsubsection{Job creation and contracts with farmers}

A United Nations report has shown that organic farming has the potential to create job opportunities for local people (UNDP, 1992). This study found that six of the 10 hotel/restaurants surveyed employed local farmers, though they are not included in the 'number of employees' section of Table 3. The individuals who did not hire farmers owned family-run farms or employed hotel/restaurant workers to maintain the farmland. During the busy farming seasons, these individuals worked both in the hotel/restaurant and on the organic farm. The respondents who hired farmers visited their farms and told them how to grow crops and vegetables as part of their daily schedule.

Individuals $\mathrm{C}$ and $\mathrm{M}$ had contracts with local organic farmers. Individual $\mathrm{C}$ bought organic vegetables from a particular farmer when he could not harvest enough from his own farm, and paid directly to that farmer almost the same price he would have paid to a vendor in the market. Individual $\mathrm{C}$ had to find an organic farmer himself because organic products cannot be reliably distinguished from non-organic products in the markets. Individual $\mathrm{M}$ organized farmers groups in his home village and sold produce such as vegetables, dried medicinal herbs and honey in Pokhara. This shows that tourism also plays an important role in the marketing of organic products.

\subsubsection{Organic farming in rural development}

Some individuals began their organic activities to contribute to the development of the rural areas around Pokhara. Such individuals, for example individual A, owned relatively large farms, and tried to increase farmer incomes by giving farmers knowledge of organic farming and the opportunity to discuss methods to achieve sustainable development in rural areas. Although farmers initially had difficulty understanding organic farming, they tried to develop their villages into a sustainable rural tourist area following the direction provided by individual A.

Another individual, individual $\mathrm{M}$, who is a small organic shop owner in Pokhara, organized three farmers' groups in his home village and held training sessions to promote organic practices. This activity had two purposes. One was to supply organic products commercially and thus increase the quality of products available in the local market. The shop sells natural honey, dried vegetables, 
organic beans, organic tea, herbal medicines and soaps, all purchased directly from a nearby village from which the shop owner originates. The other purpose was to diffuse knowledge of organic farming and sustainable development through organizing farmers groups in the village. This activity not only creates income for farmers, but is also useful for capacity building. Individuals in the tourism industry thus are a significant factor for the diffusion of organic farming in rural areas, resulting in the spread of knowledge of organic farming and increased income for rural development.

\section{Conclusion}

Despite growing concern about the human health risks of pesticides, the natural environment and ecosystems in Nepal (Atreya et al. 2012), organic farming has only emerged recently and remains in its infancy. However, in Pokhara, a famous tourist area set amidst beautiful landscapes, an increasing number of individuals involved in the tourism industry have been introducing organic-related activities. This study investigated the motivations for and factors related to the introduction of such activities.

Motivations varied according to when individuals commenced their organic activities; early starters wanted to develop their farms, while late starters wanted to benefit from the added value of organic products. This phenomenon has also been observed in many previous European studies. All individuals also hoped to contribute to the development of their home villages through their organic-related activities.

The kind of organic-related activities that individuals engaged in varied depending on how the individual first encountered the term 'organic farming'. Individuals who obtained their information from foreign tourists tended to regard 'organic farming' as traditional farming. They therefore simply repackaged this traditional farming style in terms familiar to foreign tourists by commercializing their organic products in the tourism industry and local market. In contrast, the individuals who encountered the term 'organic farming' from foreign extension workers, local NGOs and the internet regarded 'organic farming' as a technologically and economically efficient style of farming, without chemical inputs. They tended to advertise their activities to profit from the added value of organic produce. 
Increasing demand for organic products among domestic consumers is important to promote organic farming in Nepal. Although Nepalese consumers have gradually become more interested in organic farming, demand for organic products remains weak (Bhatta et al., 2009). However, in Pokhara, foreign tourists have boosted demand for organic products. This in turn has promoted the diffusion of information and knowledge regarding organic farming from tourist sites back to the rural areas from which individuals involved in the tourism industry originated. Because many people are concerned with health issues and environmental conservation in both Pokhara and the surrounding rural areas, more organic-related activities targeting sustainable development can be expected in the future.

References

Adhikari, J. (2005). The Significance of Towns in Rural Development: A Case Study of Western Nepal. Studies in Nepali History and Society, 10(2), 295-319.

Adhikari, J., \& Seddon, D. (2002). POKHARA Biography of a town. Kantipath Kathmandu, Mandala Book Point.

Akiyama, A. (2012). Organic farming by small-scale farmers in a developing country: a case study of a village in Kerala, south India. Japanese Journal of Organic Agriculture Science, 3(2), 23-31.

Aoki, M. (2011). Prospects and Challenges of 'Organic' in and around Pokhara. Studies in Nepali History and Society, 16(1), 41-61.

Atreya, K., Johnsen, F. H., \& Sitaula, B. K. (2012). Health and environmental costs of pesticide use in vegetable farming in Nepal. Environment, Development and Sustainability, 14, 447493.

Bhat, B.R. (2009). Opportunity and challenge of organic certification system in Nepal. The Journal of Agriculture and Environment, 10, 124-128.

Bhatta G.D., Doppler, W. ,\& KC, K.B.(2009). Potentials of organic agriculture in Nepal. The Journal of Agriculture and Environment, 10, 1-11.

Bowler, I. (1992). Sustainable agriculture as an alternative path of farm business development. In Bowler, Bryant, Nellis (Eds.), Contemporary Rural Systems in Transaction. CAB International, New York.

CBS. (Central Bureau of Statistics).(2007). District Profiles Kaski. National Planning Commission Secretariat Government of Nepal.

CBS. (2011). Nepal Living Standards Survey 2010/11. National Planning Commission Secretariat Government of Nepal. 
Cavaco, C. (1995). Rural tourism: The creation of new tourist spaces. In A. Montanari, \& A. Williams (Eds.), European tourism: Regions, spaces and restructuring (pp. 129-149). Chichester, UK: Wiley.

Darnhofer, Ika. (2005). Organic farming and rural development: some evidence form Austria. Sociologia Ruralis, 45(4), 308-323.

Devendra, C. ,\& Thomas, D. (2001). Crop-animal interactions in mixed farming systems in Asia. Agricultural Systems, 71, 27-40.

Fisher, P. (1989). Barriers to the adoption of organic farming in Canterbury. MSc thesis Lincoln, New Zealand Centre for Resource Management Lincoln University.

Fuller, A.(1990). From part-time farming to pluriactivity: A decade of change in rural Europe. Journal of Rural Studies, 6(4), 361-373.

Gannon, A. (1994). Rural tourism as a factor in rural community economic development for economies in transition. Journal of Sustainable Tourism, 2(1+2), 51-60.

Goldberger, J.R. (2008). Diffusion and Adoption of Non-Certified Organic Agriculture: A Case Study from Semi-Arid Makueni District, Kenya. Journal of Sustainable Agriculture, 32(4), 531-564.

Greffe, X. (1992), Rural Tourism, Economic Development and Employment. Business and Jobs in the Rural World. Paris, OECD, 121-147.

Hamilton, S. \& Fischer, E.F. (2003). Non-traditional agricultural exports in highland Guatemala: Understandings of risk and perceptions of change. Latin American Research Review 38(3):, 82-110.

Hansen, B., H.F. Alroe, E. Kristensen (2001). Approaches to assess the environmental impact of organic farming with particular regard to Denmark. Agriculture, Ecosystems and Environment,55, 11-26.

Hyungsuk, C., \& Tazim, J. (2009). Tourism on organic farms in South Korea: a new form of ecotourism. Journal of Sustainable Tourism, 17(4), 431-454.

IFOAM (The International Federation of Organic Agriculture Movements) Website: http://www.ifoam.org/about_ifoam/principles/index.html. Accessed October 172012.

ISRC (Intensive Study \& Research Centre). (2008). Municipality Profile of Nepal-2008. Kathmandu.

Kafle, B. (2011). Diffusion of uncertified organic vegetable farming among small farmers in Chitwan district, Nepal: A case study of Phoolbari village. International Journal of Agriculture Research and Review, 1(4), 157-163.

Kuo, N.W., Chiu, Y.T. (2006). The assessment of agritourism policy based on SEA combination with HIA. Land use policy, 23, 560-570.

Lampkin, N. (1994). Organic farming: sustainable agriculture in practice. In: Lampkin, N., Padel, S.(Eds.), The Economics of Organic Farming. An International Perspective. CABI; Oxford.

Lane, B. (1994). What is Rural Tourism?. Journal of Sustainable Tourism, 2(1\&2), 7-21.

Maetzold, J. (2002). Nature-Based Tourism \& Agritourism Trends: Unlimited Opportunities. http://www.agmrc.org/media/cms/agritourism_E6794269B3FF6.pdf, Accessed May 112013. 
Mandal, D.N. , \& Resources, P.G.(2007). Organic farming: an ecofriendly way to sustainable agriculture. The Journal of Agriculture and Environment, 8, 115-118.

MOAC .(Ministry of Agriculture and Cooperatives). (2008). Statics of Fertilizer 2007/08. Government of Nepal.

MOAC. (2004). National Agriculture Policy. Nov. 22 2004, Government of Nepal.

OECD.(2001). Multifunctionalit: towards and analytical framework. Paris; OECD.

Opperman, M. (1996). Rural tourism in southern Germany. Annals of Tourism Research, 23(1), 86-102.

Padel, S. (2001). Conversion to organic farming: A typical example of the diffusion of an innovation?. Sociologia Ruralis, 41(1), 40-61.

Pant, K.P. (2006). Organic agriculture for sustainable development in Nepal paper presented in APO seminar on organic farming for sustainable development, Colombo, Sep 2006.

Parror, N., Olesen J.E., \& Hogh-Jensen H. (2006). Certified and non-certified organic farming in the developing world. In Halberg, N., Alroe, HF. Knusen, M T.\& Kristensen ES. Wallingford UK (Ed.) Global Development of Organic Agriculture: Challenges And Promises (pp. 154176), CABI Publishing.

Pinheiro, S, Cardosos, A. Maria, Turnes, V., Schmidt, W., Brilo, R. \& Guzzat, T. (2002). Sustainable Rural Life and Agroecology - Santa Catarina State , Brazil. In Scialabba and Hattam (eds). Organic Agriculture, Environment and Food Security. Environment and Natural Resources Service Series no. 4, FAO, Rome, (pp. 227-234).

Pokhrel, D.M., \& Pant, K.P. (2009). Perspectives of organic agriculture and policy concern in Nepal. The Journal of Agriculture and Environment, 10, 88-89.

Pretty, J. (1995). Regenerating Agriculture. Policies and Practice for Sustainability and SelfReliance. Earthscan, London.

Privitera, D. (2010). The importance of organic agriculture in tourism rural. Applied Studies APSTRACT-Agribusiness and Commerce, 4(1-2), 50-64.

PTC (Pokhara Tourism Council). (2008). Pokhara Tourism Mirror Vol.1 Issue 2.

Ramesh, P. Singh, M., \& Subba, R A. (2005). Organic farming: Its relevance to Indian context. Current Science, 88, 561-568.

Rogers, E.M. (1995). Diffusion of Innovations, Fourth Edition. New York, The Free Press.

Scofeld, A., (1986). Organic farming -the origin of the name. Biological Agriculture and Horticulture 4, 1-5.

Scialabba, N. (2000). Opportunities and constrains of organic agriculture, A sociological analysis. Rome,

Sharma, A.K.(2001). A Handbook of Organic Farming, Agrobios (India), Jodhpur.

Stolze, M., Piorr, A., HaÈ ring, A., Dabbert, S. (2000). Environmental impacts of organic farming in Europe. Organic Farming in Europe: Economics and Policy6. Stuttgart-Hohenheim 2000. Department of Farm Economics, University of Hohenheim, Germany.

UNDP. (1992). Benefits of diversity: an incentive towards sustainable agriculture. UNDP New York. 
Weymes, E. (1990). The market for organic foods: a Canada-Wide Survey. Faculty of Administration, University of Regina, Saskatchewan.

Willer, H., \& Yussefi, M, (Eds.) (2007) The World of Organic Agriculture - Statistics and Emerging Trends 2007.Frick and Bonn, IFOAM\&FiBL.

Willer, H,. \&and Yussef, M (Eds.) (2005) The World of Organic Agriculture Statistics and Emerging Trends 2005.Frick and Bonn, IFOAM\&FiBL

Willer,H., \& Kilcher, L (Eds.) (2009) The World of Organic Agriculture-Statistics and Emerging Trends 2009. Frick and Bonn, IFOAM\&FiBL

Willer,H., \& Kilcher, L (Eds.) (2012) The World of Organic Agriculture-Statistics and Emerging Trends 2012. Frick and Bonn, IFOAM\&FiBL

Willer,H., \& Kilcher, L (Eds.)(2013) The World of Organic Agriculture 2013. Frick and Bonn, IFOAM\&FiBL

Wu, B. \& Pretty, J. (2004). Social connectedness in marginal rural China: the case of farmer innovation circles in Zhidan, north Shaanzi. Agriculture and Human, 21, 81-92. 
Table 1 Quantitative measures of organic farming in Nepal

\begin{tabular}{l|c|c|c|c|c}
\hline & 2001 & 2005 & 2007 & 2009 & 2011 \\
\hline The number of organic farms & 26 & - & 245 & - & 247 \\
The number of organic producers & - & 1,247 & 1,424 & 1,470 & - \\
Organic land (ha) & 45 & 1,000 & 8,187 & 9,789 & 9,892 \\
Organic share of all agricultural land(\%) & 0.00 & 0.02 & 0.20 & 0.23 & 0.23 \\
\hline
\end{tabular}

Source: Willer,H \& Kilcher, L(2013)(2012)(2009), Willer, H \& Yussefi, M (2007)(2005)

Table 2 Categorization of motivating factors for converting to organic farming in this study

\begin{tabular}{|c|c|c|c|}
\hline \multirow{13}{*}{$\begin{array}{l}\text { Motivations } \\
\text { for } \\
\text { introducing } \\
\text { organic } \\
\text { farming }\end{array}$} & \multirow{6}{*}{$\begin{array}{c}\text { Farming related } \\
\text { motives }\end{array}$} & \multirow{2}{*}{$\begin{array}{l}\text { Husbandry and } \\
\text { technical reasons }\end{array}$} & Animal health problems \\
\hline & & & Soil fertility and erosion problems \\
\hline & & \multirow{4}{*}{ Financial Motives } & Solve existing financial problems \\
\hline & & & Secure future of farm \\
\hline & & & Cost saving \\
\hline & & & Premium marketing \\
\hline & \multirow{7}{*}{ Personal motives } & Personal health & Personal and family health problems \\
\hline & & \multirow{6}{*}{ General concerns } & Ergonomic reasons \\
\hline & & & Stewardship \\
\hline & & & Food quality \\
\hline & & & Conservation \\
\hline & & & Environment \\
\hline & & & Rural development \\
\hline \multicolumn{4}{|c|}{ Size of land for organic farming } \\
\hline
\end{tabular}

The time when individuals first knew the term

The term "organic"

How individuals first get the information on the term

The concept of the term for individuals 
Table 3 Motivations for and factors related to organic activities

\begin{tabular}{|c|c|c|c|c|c|c|c|c|c|c|c|c|c|c|c|}
\hline & & & \multicolumn{10}{|c|}{ Hotel/Restaurant } & \multicolumn{3}{|c|}{ Organic shop } \\
\hline & & & $\mathrm{A}$ & $\mathrm{B}$ & $\mathrm{C}$ & $\mathrm{D}$ & $\mathrm{E}$ & $\mathrm{F}$ & G & $\mathrm{H}$ & $\mathrm{I}$ & $\mathrm{J}$ & $\mathrm{K}$ & $\mathrm{L}$ & $\mathrm{M}$ \\
\hline \multicolumn{3}{|c|}{ Year when organic activities were initiated } & 1979 & 1988 & 1989 & 1997 & 1999 & 1999 & 2000 & 2006 & 2006 & 2009 & 2006 & 2008 & 2008 \\
\hline \multirow{3}{*}{\multicolumn{2}{|c|}{ Information about the individual }} & Age & 65 & 37 & 26 & 51 & 42 & 37 & 35 & 32 & 30 & 50 & 40 & 35 & 40 \\
\hline & & Former job & $\begin{array}{l}\text { Medical } \\
\text { herb shop }\end{array}$ & Farmer & Farmer & Farmer & Farmer & Farmer & Farmer & $\begin{array}{l}\text { Hotel } \\
\text { staff }\end{array}$ & Farmer & Farmer & Farmer & - & Farmer \\
\hline & & NGO member & 0 & $x$ & $x$ & 0 & $x$ & 0 & $x$ & $\bigcirc$ & $x$ & $x$ & $\bigcirc$ & 0 & 0 \\
\hline \multicolumn{3}{|c|}{ Number of employees } & 10 & 9 & 5 & 4 & 5 & 2 & 5 & 3 & 4 & 4 & 1 & 2 & 2 \\
\hline \multirow{2}{*}{\multicolumn{2}{|c|}{ Size of land for organic farming (ha) }} & Paddy & 3.2 & 0 & 0 & 1 & 0 & 0 & 0 & 0 & $*$ & 0 & 0 & 0 & 0 \\
\hline & & Non-paddy farm & 0.4 & 0.1 & 0.6 & 0 & 4 & 0.05 & 4 & 0.5 & 0.05 & 0.5 & 0 & 0 & 0 \\
\hline \multirow{3}{*}{\multicolumn{2}{|c|}{ The term "organic" }} & When first known & 1989 & 1988 & 2002 & 1997 & 1994 & 1999 & 1999 & 1999 & 2006 & 1997 & 2005 & 2008 & 2002 \\
\hline & & How first known & FT & FT & FT & FT & $\mathrm{FE}$ & FT & $\mathrm{FE}$ & I & FT & $\mathrm{OH}$ & NGO & NGO & $\mathrm{NF}$ \\
\hline & & Concept ${ }^{2}$ & $\mathrm{~T}$ & $\mathrm{~T}$ & $\mathrm{~T}$ & $\mathrm{~T}$ & $\mathrm{O}$ & $\mathrm{T}$ & $\mathrm{O}$ & $\mathrm{O}$ & $\mathrm{T}$ & $\mathrm{O}$ & $\mathrm{O}$ & $\mathrm{O}$ & $\mathrm{T}$ \\
\hline \multirow{9}{*}{$\begin{array}{l}\text { Motivations for } \\
\text { introducing organic } \\
\text { farming }\end{array}$} & \multirow{3}{*}{$\begin{array}{l}\text { Farming } \\
\text { related } \\
\text { motives }\end{array}$} & Soil fertility & $\bigcirc$ & 0 & & $\bigcirc$ & 0 & & & & & & & & \\
\hline & & Cost saving & & & & $\bigcirc$ & & & & & & & & & \\
\hline & & Premium marketing & & & & & $\bigcirc$ & & $\bigcirc$ & 0 & 0 & $\bigcirc$ & $\bigcirc$ & 0 & $\bigcirc$ \\
\hline & \multirow{6}{*}{$\begin{array}{c}\text { Personal } \\
\text { motives }\end{array}$} & Health problems & $\bigcirc$ & $\mathrm{O}$ & & $\mathrm{O}$ & 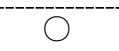 & $\mathrm{O}$ & $\mathrm{O}$ & & $\mathrm{O}$ & & & & $\mathrm{O}$ \\
\hline & & Food quality & $\bigcirc$ & $\bigcirc$ & & $\bigcirc$ & & $\bigcirc$ & & & $\bigcirc$ & & & & \\
\hline & & Conservation & $\bigcirc$ & & & & & & & & & & $\bigcirc$ & & \\
\hline & & Environment & $\bigcirc$ & & & & $\bigcirc$ & & & & & $\bigcirc$ & $\bigcirc$ & $\bigcirc$ & \\
\hline & & Rural development & $\bigcirc$ & & & & & $\bigcirc$ & & $\bigcirc$ & & $\bigcirc$ & & & $\bigcirc$ \\
\hline & & Satisfying guests & & & 0 & 0 & & & & & $\bigcirc$ & & & & \\
\hline \multicolumn{3}{|c|}{ Number of farmers employed } & 6 & 2 & & 2 & 12 & & 7 & 4 & & & & & \\
\hline \multicolumn{3}{|c|}{ Number of Contracted farmers } & & & 1 & & & & & & & & & & 3 \\
\hline
\end{tabular}

1) FT: Foreign Tourists. He/she learned the term ‘organic’ from foreign tourists. FE: Foreign Extension workers. He/she learned the term 'organic’ from foreign extension workers. I: Internet.

He/she learned the term 'organic' through the internet or from books. OH: Other Hotels. He/she learned the term 'organic' from other hotels conducting organic-related activities. NGO: He/she learned the term 'organic' from NGOs conducting organic-related activities. NF: Neighbor Farmers. He/she learned the term 'organic' from neighbors.

2) T: Traditional way. He/she regards 'organic’ as traditional farming. O: Organic Farming. He/she regards 'organic’ as technologically and economically efficient organic farming. 
